\title{
Recovery of surface-dwelling assemblages (Coleoptera: Carabidae, Staphylinidae) during clear-cut originated reforestation with native tree species
}

\section{DÁVID D. NAGY1 \\ TIBOR MAGURA ${ }^{2}$ \\ SZABOLCS MIZSER ${ }^{1}$ \\ ZSUZSANNA DEBNÁR ${ }^{1}$ \\ BÉLA TÓTHMÉRÉSZ}

'MTA-DE Biodiversity and Ecosystem Services Research Group, Egyetem sq. 1, Debrecen H-4032 Hungary

${ }^{2}$ University of Debrecen, Department of Ecology P.0.Box 400, Debrecen, H-4002 Hungary

\section{Correspondence:}

Dávid D. Nagy

E-mail: nagydavin@gmail.com

Keywords: carabids; clear-felling; forest specialist species; Rényi diversity index; silvicultural cycle; succession, staphylinids
Received January 15, 2016

Revised July 15, 2016.

Accepted July 20, 2016

\begin{abstract}
Background and purpose: Timber-oriented forest management has an important impact on biodiversity in forest ecosystems. Recovery dynamics of two groups of beetles (Coleoptera: Carabidae, Staphylinidae) were studied after reforestation with native English oak (Quercus robur). We expected that reforestation with heavy site preparation causes a shift in the diversity of surface-dwelling beetles in early phases of reforestation. Moreover, we tested the habitat specialist hypothesis, assuming that diversity of forest specialist species will be lower in early phases with open canopy than later phases of reforestation after the canopy closure.
\end{abstract}

Materials and methods: We compared litter sifter samples among mature (130-year-old) oak forest, and recently established (5-year-old), young (15-year-old), middle-aged (45-year-old) reforestations.

Results: Our results showed that diversity of ground beetles was the highest in the recently established reforestation, while it was the lowest in the mature oak forest. Contrarily, diversity of rove beetles was the lowest in recently established reforestation and it was the highest in the mature oak forest. In agreement with the habitat specialist hypothesis, the diversity of forest specialists of both taxa was lower in the recently established reforestation than in the young and middle-aged reforestations as well as mature forest.

Discussion: Our results suggested that clear-cutting of mature forest, site preparation before reforestation and cultivation by light tilling in early phases of reforestation have detrimental effects on forest specialist rove beetles and ground beetles. However, reforestation with native species could be a feasible management method in pannonic mesophile sand steppe, because forest specialist species can recover after the canopy closure.

\section{INTRODUCTION}

Timber-oriented forest management has a crucial impact on the structure and function of forest ecosystems. It also has a harmful effect on biodiversity, as several groups of animals, fungi, and plants are sensitive to anthropogenic disturbance and environmental changes ( 1 , 2). The cover of planted and naturally regenerated forests with human interventions accounted for 64 percent of the world's forest area in 2010, while cover of primary forests has been steadily decreasing since 2000 (3). Recent European Union commitments have highlighted the need 
to halt biodiversity loss and promote sustainable management, and have included in the Natura 2000 network (4). In spite of these measures the designated forest area for conservation of biodiversity was still 4.6 percent of European forests in 2015 (5).

During forest management there are important decisions; selection of tree species (native, non-native species), sustainable practices, such as even-aged (modified clearcutting, seed tree method and shelterwood harvesting) and uneven-aged (group selection, single tree selection) regeneration methods $(2,6)$. Well-chosen forest practices contribute to maintaining forest biodiversity, because these practices have less intensive and less harmful impacts on environment than conventional clear-cutting model with soil preparation (7). Nevertheless, the conventional clear-cutting of mature forest stands and soil preparation before reforestation are still widely used throughout Europe (8). This forest practice is also commonly used by forestry in north-eastern part of the Great Hungarian Plain, Hungary (2). Several previous studies revealed that clear-cutting of mature forest and reforestation with coniferous tree species alter the original landscape and cause changes in environmental conditions, resulting a shift in composition and diversity of surface-dwelling beetle assemblages (9-11). However, only a few papers focus on recovery dynamics of surface-dwelling beetle assemblages in chronosequence of deciduous reforestation after clear-cutting $(2,12)$.

Among surface-dwelling beetles, the ground beetles (Coleoptera: Carabidae) are the most frequently studied family with respect to the effects of forest management on invertebrates (13). Ground beetles are good colonisers and generalist predators or polyphagous feeders, taxonomically and ecologically well-known and they are sensitive to environmental changes. Study of other taxa may also be expedient to get more details about the effects of forest management practices, because different taxa can respond differently to anthropogenic and natural disturbances (13). Rove beetles (Coleoptera: Staphylinidae) are also a common beetle family of litter and soil fauna (14). Similarly to ground beetles many species are good flier and predators of arthropods. However, some species are flightless and they utilize other food resources (decaying materials, pollen, fungi). They respond sensitively to habitat alteration and human disturbance, furthermore they have high species richness and abundance in worldwide (except open water surface and area above snowline), allowing their investigation as bioindicator $(14,15)$.

In this paper we focused on the recovery dynamic of two surface-dwelling groups (ground beetles and rove beetles) in stages of a silvicultural cycle: 130-year-old mesophile sand steppe oak forest (Convellario-Quercetum roboris), and recently established, young and middle-aged reforested stands of English oak (Quercus robur). We expected that (i) heavy site preparation before reforestation (clear-cutting, grubbing, tilling) will cause a shift in diversity of surface-dwelling beetles in early phases of reforestation (1-5 years after the clear-cutting) $(2,16)$. We also expected that disturbance generated by site preparation will reduce with ageing of reforested stands and the environmental conditions become more similar to the mature native forest after the canopy closure, contributing to the recovery of forest specialist surface-dwelling species (2). Habitat specialist hypothesis is one of the most frequently used assumptions to test of human disturbances, supposing that characteristic specialist species of original habitat will decrease after human disturbance (17). Therefore, we tested the (ii) habitat specialist hypothesis, assuming that diversity of forest specialist ground beetle and rove beetle assemblages will be lower in the recently established reforestation than in the young and middleaged reforestations as well as in the mature forest.

\section{MATERIAL AND METHODS}

\section{Study area}

The study area was located in the North-Eastern part of the Great Hungarian Plain near to Debrecen city in Hungary ( $\left.47^{\circ} 32^{\prime} \mathrm{N} ; 2^{\circ} 38^{\prime} \mathrm{E}\right)$. Pannonic mesophile sand steppe oak forest is the typical native association in this region (18). Chronosequence of a silvicultural cycle was selected to study the recovery dynamic of surface-dwelling beetles: (i) mature mesophile sand steppe oak forest (130-year-old) that had been selectively cut historically but never clear-felled; the English oak was the most numerous tree species in the closed tree canopy; shrub layer was moderate (Crataegus monogyna, Sambucus nigra, Acer campestre and Prunus serotina); in the herb layer among others Polygonatum latifolium, Alliaria petiolata, Salvia glutinosa, Circaea lutetiana, Impatiens parviflora and Geum urbanum were present. In the mature oak forest the fallen, decaying woody materials were abundant. The (ii) recently established English oak reforestation (5-year-old) with open, bare soil surface. It was cultivated by light tilling during forest management. Quercus robur and Robinia pseudoacacia were present in the shrub layer and the understory vegetation was dense (Convallaria majalis, Polygonatum latifolium, Calamagrostis epigeios, Elymus caninus, Digitaria sanguinalis). In the (iii) young English oak reforestation (15-year-old) with closed canopy cover, the shrub layer consisted of Acer campestre and Prunus seroti$n a$, while in the herb layer Chelidonium majus, Bromus sterilis, Elymus caninus were numerous. The (iv) middleaged English oak reforestation (45-year-old); in the shrub layer individuals of Prunus serotina showed a scattered pattern, while in the herbaceous layer Alliaria petiolata, Urtica dioica, Impatiens parviflora and Dactylis polygama were most frequent.

All studied reforestations were established after clearcutting of mature oak forest stands by planting native, English oak acorns. Fallen and decaying wood was re- 
moved from the reforestations during management. For spatial replication two separated stands ( $>3 \mathrm{ha}$ ) of stages of the silvicultural cycle were investigated. Surface-dwelling beetle assemblages could be considered as spatially independent replicates due to distance $(>300 \mathrm{~m})$ and features (footpath, dirt roads and other forest stands) between the studied stands.

\section{Sampling design}

Both studied taxa were collected at each stand using litter sifting method. Previous studies showed that this method is efficient to collect arthropods which are active in soil, woody and litter debris $(19,20)$. Five randomly selected litter sampling plots $(5 \times 5 \mathrm{~m})$ were assigned at each replicates. In the sampling plots a metal frame $(25 \times 25 \times 5 \mathrm{~cm})$ was used to select the sampling quadrate, whereof soil, litter and woody debris were removed and those were sifted with a litter sifter (6). Sampling quadrates were located randomly in sampling plots. These plots were at least $15-25 \mathrm{~m}$ apart from each other to provide statistically independent samples, and $30 \mathrm{~m}$ from the forest edge in order to avoid any edge effect $(6,21,22)$. Overall there were 40 litter samples $(4$ stages $\times 2$ replicates $\times 5$ litter samples). Litter samples were collected every third week from April to October in 2011. Collected beetles were extracted manually from each sample in the laboratory and preserved in 70\% alcohol (23).

\section{Data analysis}

All studied surface-dwelling beetles in litter sifter samples were identified to species level using standard keys (24-26). For the statistical analyses, we pooled samples for the whole year.

Diversity profiles of the ground beetle and rove beetle assemblages were calculated using the Rényi diversity function by BiodiversityR program package $(27,28)$.

The Rényi diversity, $H R(\alpha)$ is defined as:

$$
H R(\alpha)=\frac{1}{1-\alpha}\left(\log \sum_{i=1}^{S} p_{i}^{\alpha}\right),
$$

where $p_{i}$ is the abundance of the $i$-th species, $S$ the total number of species and $\alpha$ is the scale parameter $(\alpha \geq 0, \alpha \neq 1)$.

At four values of the scale parameter $\alpha$, the Rényi diversity index value relates to classical diversity indices (29, 30): (i) at $\alpha=0$, the value of the Rényi diversity is the logarithm of the number of species; (ii) at $\alpha \rightarrow 1$, the Rényi diversity is the same as the Shannon diversity; (iii) at $\alpha=2$, the value of the Rényi diversity is related to the Simpson diversity, and (iv) at $\alpha \rightarrow+\infty$, the value of the Rényi diversity is closely related to the Berger-Parker dominance index (31).

The Rényi diversity is sensitive to rare species at small values of the scale parameter; as the scale parameter in- creases, the diversity value is increasingly influenced by the common species. Near infinity, only the abundance of the most common species will determine the diversity. The assemblage whose diversity profile runs above the other ones (the diversity profiles do not intersect each other) is unequivocally more diverse than the other assemblages. By contrast, if the profiles cross each other, the assemblages cannot be unequivocally ordered, because one assemblage is more diverse for the rare species, while another is more diverse for the common ones (17).

Due to different species pools and local conditions the diversity of the total assemblage may show idiosyncratic responses to different stages of silvicultural cycle; therefore, the assemblages of forest specialist species were also studied. Categorisation of a species as „forest specialist species" was based on the classification of Koch (32) and Hůrka (26) and also on our field experience (Appendix 1).

\section{RESULTS}

Altogether 1447 individuals of studied surface-dwelling beetles belonging to 135 species were trapped during the study; of which 314 individuals were ground beetles, belonging to 43 species and 1133 individuals were rove beetles, representing 92 species. Number of ground beetle species (26 including 2 forest specialist species) was the highest, while the number of rove beetle species (18 including 0 forest specialist species) was the lowest in the recently established reforestation; 7 forest specialist species from 17 ground beetle species and 8 forest specialist species from 46 rove beetle species were captured in the young reforestation; 17 ground beetle species ( 8 forest specialist species) and 45 rove beetle species ( 8 forest specialist species) were collected in the middle-aged reforestation; the lowest ground beetle species richness (12 species including 5 forest specialist species) and the highest rove beetle species richness (58 species including 11 forest specialist species) were observed in the mature forest (Appendix 1).

Differences were observed in the diversity of ground beetle and rove beetle assemblages among the studied stages of silvicultural cycle. Our results showed that the recently established reforestation supported the most diverse ground beetle assemblage, and the assemblage was the least diverse in the mature oak forest (Fig. 1A). Contrary to ground beetles, the diversity of rove beetle assemblages was the lowest in the recently established reforestation and the highest in the mature oak forest (Fig. 1B). Diversity profiles of both beetle assemblages in young and middleaged reforestations are not comparable, since the diversity profiles are intersected to each other (Fig. 1A and B).

The diversity of forest specialist ground beetle assemblages was the lowest in the recently established reforestation (Fig. 2A). Middle-aged reforestation had more diverse forest specialist ground beetle assemblage over the entire range of the scale parameter than recently estab- 
A)

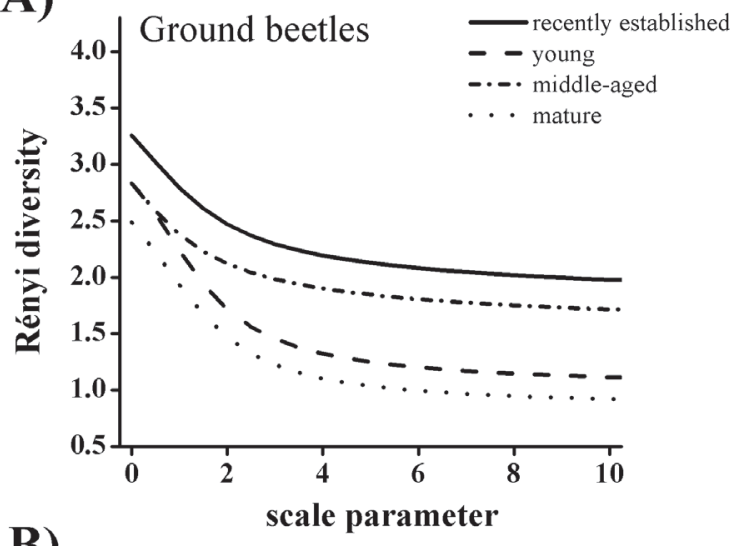

B)

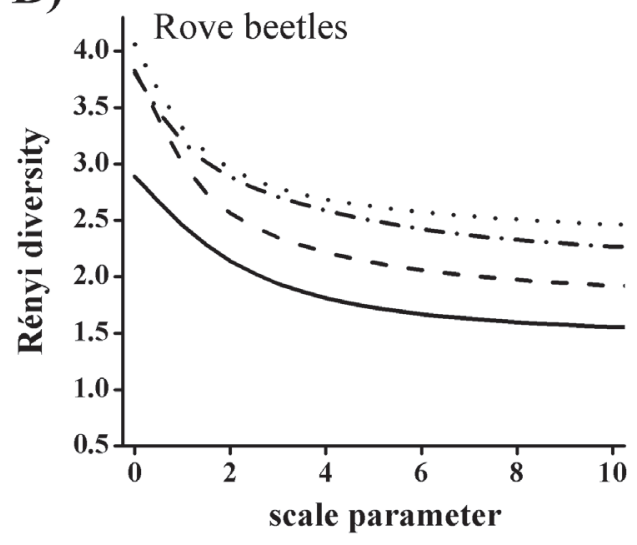

Fig. 1. Diversity profiles of ground beetle (A) and rove beetle (B) assemblages with Rényi diversity index family. The solid line denotes recently established reforestation, the dashed line young reforestation, the dash-dot line middle-aged reforestation and the dotted line mature oak forest.

lished and young reforestations. Forest specialist ground beetle assemblages of both the young and the middle-aged reforestations crossed the diversity profile of ground beetle assemblage of mature forest, therefore these cannot be unequivocally ordered (Fig. 2A).

There were no forest specialist rove beetles in the recently established reforestation, evidently resulted zero diversity (Fig. 2B). Diversity profiles of forest specialist rove beetle assemblages of the mature oak forest, the young and the middle-aged reforestations intersected to each other; therefore, these cannot be unequivocally ordered (Fig. 2B).

\section{DIscussion}

\section{Diversity of ground beetles in reforestations}

Clear-cutting and soil preparation before reforestation and the cultivation by light tilling during the management of the reforested stands cause many forms of distur- bance, such as degradation, fragmentation and isolation of original habitats (2). In spite of dramatic alteration of mature forest stands our results showed that the diversity of ground beetle assemblages increased in the recently established reforestation. Similarly to our results several previous studies reported diverse ground beetle assemblages in recently established reforestation after $1-5$ years of clear-cutting $(2,33,34)$. In these studies the elevated diversity was explained by the colonization of open-habitat and habitat generalist species with high dispersal ability and the survival of some forest specialist ground beetle species $(2,35)$. However, other studies found that heavy site preparation after the clear-cutting (grubbing, tilling, deep loosening, burning) causes significant damage in ground beetle diversity in deciduous and coniferous nonnative reforestations $(9,12)$. The reason for this is that heavy site preparation eliminates microhabitats required by the forest specialist species causing the disappearance of these species from the prepared, recently established
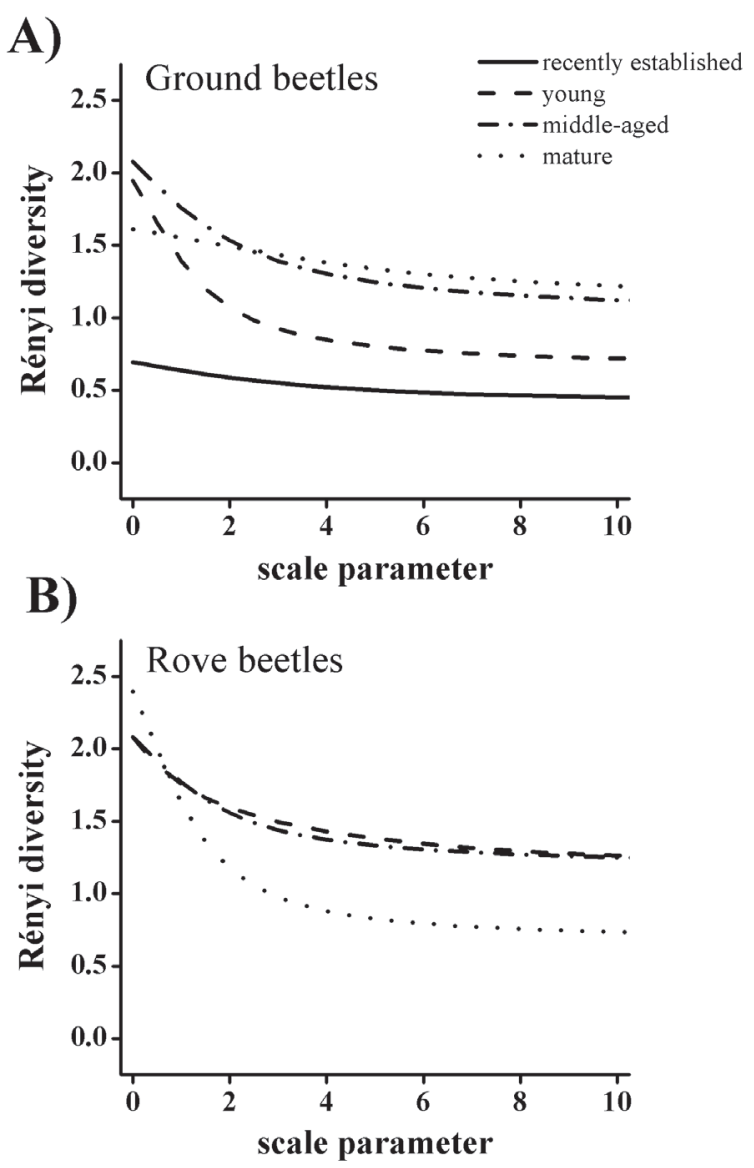

Fig. 2. Diversity profiles of forest specialist ground beetle $(A)$ and rove beetle (B) assemblages with Rényi diversity index family. There were no forest specialist rove beetles in the recently established reforestation; thus, the diversity profile of this assemblage is not displayed. The solid line denotes recently established reforestation, the dashed line young reforestation, the dash-dot line middle-aged reforestation and the dotted line mature oak forest. 
reforestations (9). Moreover, reforestation with non-native tree species hampers the regeneration of favourable environmental conditions; thus, many native forest specialist species may not find their preferred habitat requirements even after 40 years of reforestation $(6,9)$.

It has been shown that overall diversity is not the most appropriate indicator of the impacts of silvicultural cycle on surface-dwelling beetles $(2,16)$. Instead of that, studies based on functional traits of the surface-dwelling beetle species are efficient approaches to follow this issue, and understand the requirements of specialist species $(2,6$, 15). Our findings suggest that clear-cutting of mature forest stands and reforestation with native tree species is not necessarily detrimental to ground beetle diversity, because early phases of reforestation (1-5 years after clearcutting) provide habitat for species that are not present in the mature forest. These ground beetle species have high dispersal ability and ecological flexibility; therefore, they can colonize easily the reforested stands after some years of clear-cutting $(2,35)$.

Although, the diversity of forest specialist assemblage reduced in the recently established reforestation, some forest specialist species could survive in these habitats. Thus, reforestation with native tree species resulted in high ground beetle diversity by colonization of good colonizer species from neighbouring habitats and survival of some forest specialist species in early phases of the reforestation. With canopy closure the diversity of ground beetle assemblages declined, while the diversity of forest specialist assemblages increased. Elevated forest specialist ground beetle diversity in later phases of the silvicultural cycle (after canopy closure) showed that clear-cutting and subsequent site preparation have a particularly harmful effect on forest specialist assemblages in the early phases of reforestation, as it was predicted by the habitat specialist hypothesis.

\section{Diversity of rove beetles in reforestations}

Reforestation with native tree species clearly affected the rove beetle diversity, as their assemblages were less diverse in younger reforestation than in the mature oak forest. Similarly, in Hungary the overall abundance and species richness of rove beetles were significantly lower in 40 -year-old native reforestation and non-native plantations than in 135-year-old mature oak forest (6). However, in China after 40 years of logging of climax forest, Luo et al. (36) found no significant differences in the rove beetle diversity between coniferous and deciduous reforestations and the control mature forest ( $\approx 100$-year-old). Inconsistent results in rove beetle diversity were also found in previously published studies investigating forest succession $(13,16,34,37)$. Our results demonstrated that total diversity of rove beetles is higher in later phases than in recently established reforestation. This result suggests that clear-cutting and soil preparation (grubbing, deep loosening) before reforestation and cultivation by light tilling during the forest management had detrimental effects on the rove beetle diversity in early phases of native oak reforestation. However, with ageing of the reforested stands the environmental conditions (temperature, soil moisture, $\mathrm{pH}$ ) and habitat structure (closed canopy cover, native litter and woody debris) may become more similar to those of mature oak forest and the rove beetles can partially recover $(2,6)$.

Almost all studies suggested that canopy closure and increasing similarity in structure, microhabitats and environmental conditions between the reforestations and the mature forests could be a key factor for some forest specialist species to recolonize the reforestations $(12,16$, $34,38)$. In fact, the diversity of forest specialist rove beetles was lower in the recently established reforestation than in the young and middle-aged reforestations as well as the mature forest, in accordance with the hypothesized decrease of forest specialist species in highly disturbed (cultivated by light tilling) recently established reforestation (17).

Study of rove beetles requiring specific microhabitat, microclimate and substrates may provide more details about the effects of forest management, since several microhabitats (nests, microcaves, deadwoods) and substrates (decaying fruits, litter, feces, fungi) are key components of biodiversity in forests $(1,39)$. These components are eliminated during the intensive forest management, influencing the distribution of rove beetles requiring specific microclimate, microhabitats and substrates (15). Nagy et al. (6) showed that the diversity of hygrophilous and decaying material dependent rove beetles were significantly higher in the mature oak forest than in the younger reforestations. Mature oak forest has more favourable microclimate, microhabitats and substrates for rove beetles requiring high soil moisture and decaying organic materials than reforestations $(1,6)$. Presence of suitable microclimate, microhabitats and substrates contributes to the elevated rove beetle diversity in mature oak forest, while lack of those hampers the recovery of hygrophilous and decaying material dependent rove beetle species even after 40 years of reforestation (6). Thus, despite of similarity in forest specialist's diversity between the later phases of silvicultural cycle (young, middle aged reforestations and mature forest) the rove beetles requiring specific microclimate, microhabitats and substrates may be a key contribution to increasing of rove beetle diversity in mature forest.

\section{CONCLUSION}

Our results demonstrated that ground beetles and rove beetles respond differently to reforestation with native tree species after clear-cutting of mature oak forest. The diversity of ground beetle assemblages was higher, while the 
diversity of rove beetles was lower in the recently established reforestation compared to that of mature forest. However, in case of both taxa the diversity of forest specialist assemblages showed consistent results, as diversity of the forest specialist species was lower in recently established reforestation than in mature forest. Most of the studies focus on overall species richness of arthropods, however some species may benefit and others suffer from the habitat alteration caused by forest management (2). It is crucial to evaluate the effects of forest management on specialist species and try to find an alternative management practice which eliminate or reduce the harmful effects on biodiversity. Forest management treatments that do not alter drastically and permanently the environmental conditions, microhabitats and substrates could be appropriate methods in maintaining of the biodiversity. Therefore, we recommend that heavy site preparation (clear-cutting, grubbing, deep loosening) and management practices (light tilling) should be omitted during the reforestation and cultivation of the reforested stands in order to maintain the diversity of surface-dwelling beetles in managed forests. The uneven-aged management methods using selection cuttings have become more popular in Europe and it seems to be an appropriate method to maintain mature or late-successional forest characteristics and species assemblages $(2,40-42)$.

Aknowledgement: The authors are thankful for assistance of András Kelemen, Gyula Szabó and Bence Tajthi. We are grateful to György Makranczy and László Ádám for helps in identification of rove beetles. We thank the help of the Hortobágy National Park Directorate during fieldworks. We are also grateful to European Union and the State of Hungary, co-financed by the European Social Fund SROP4.2.2.B-15/1/KONV2015-0001, the Hungarian Academy of Sciences and the Hungarian Research Found (OTKA K-116639) for supporting this research. The research of Dávid Nagy, Szabolcs Mizser and Zsuzsanna Debnár was supported by the European Union and the State of Hungary, co-financed by the European Social Fund in the framework of TAMMOP 4.2.4.A/2-11-1-2012-0001 'National Excellence Program'.

\section{REFERENCES}

1. PAILLET Y, BERGÉS L, HJÄLTÉN J, ÓDOR P, AVON C, BERNHARDT-RÖMERMANN M, BIJLSMA RJ, DE BRUYN L, FUHR M, GRANDIN U, KANKA R, LUNDIN L, LUQUE S, MAGURA T, MATESANZ S, MÉSZÁROS I, SEBASTIÁ MT, SCHMIDT W, STANDOVAR T, TÓTHMÉRÉSZ B, UOTILA A, VALLADARES F, VELLAK K, VIRTANEN R 2010 Biodiversity Differences between Managed and Unmanaged Forests: Meta-Analysis of Species Richness in Europe. Conserv Biol 24: 1157-1160 http://dx.doi.org/10.1111/j.1523-1739.2010.01543.x

2. MAGURA T, BOGYÓ D, MIZSER S, NAGY DD, TÓTHMÉRÉSZ B 2015 Recovery of ground-dwelling assemblages during reforestation with native oak depends on the mobility and feeding habits of the species. Forest Ecol Manage 339: 117-126 http://dx.doi.org/10.1016/j.foreco.2014.12.015
3. FAO 2010 Global Forest Resources Assessment 2010. Food and Agriculture Organization of the United Nations, Rome, p 343

4. PARVIAINEN J, BOZZANO M, ESTREGUIL C, KOSKELA J, LIER M, VOGT P, OSTAPOWICZ K 2007 Maintenance, conservation and appropriate enhancement of biological diversity in forest ecosystems. In: Köhl M, Rametsteiner E (eds). State of Europe's Forests 2007 - the MCPFE report on sustainable forest management in Europe Ministerial Conference on the Protection of Forests in Europe. Liaison Unit, Warsaw, pp 45-72

5. MORALES-HIDALGO D, OSWALT SN, SOMANATHAN E 2015 Status and trends in global primary forest, protected areas, and areas designated for conservation of biodiversity from the Global Forest Resources Assessment 2015. Forest Ecol Manage 352: 68-77 http://dx.doi.org/10.1016/j.foreco.2015.06.011

6. NAGY DD, MAGURA T, DEBNÁR Z, HORVÁTH R, TÓTHMÉRÉSZ B 2015 Shift of rove beetle assemblages in reforestations: Does nativity matter? J Insect Conserv 19: 1075-1087 http://dx.doi.org/10.1007/s10841-015-9823-0

7. ROSENVALD R, LÖHMUS A 2008 For what, when, and where is green-tree retention better than clear-cutting? A review of the biodiversity aspects. Forest Ecol Manage 255: 1-15 http://dx.doi.org/10.1016/j.foreco.2007.09.016

8. HODECEK J, KURAS T, SIPOS J, DOLNY A 2015 Post-industrial areas as successional habitats: Long-term changes of functional diversity in beetle communities. Basic Appl Ecol 16: 629640 http://dx.doi.org/10.1016/j.baae.2015.06.004

9. MAGURA T, TÓTHMÉRÉSZ B, ELEK Z 2003 Diversity and composition of carabids during a forestry cycle. Biodivers Conserv 12: 73-85 http://dx.doi.org/10.1023/A:1021289509500

10. NIEMELÄ J, KOIVULA M, KOTZE DJ 2007 The effects of forestry on carabid beetles (Coleoptera: Carabidae) in boreal forests. J Insect Conserv 11: 5-18 http://dx.doi.org/10.1007/s10841-006-9014-0

11. KOIVULA MJ 2011 Useful model organisms, indicators, or both? Ground beetles (Coleoptera, Carabidae) reflecting environmental conditions. Zookeys 100: 287-317 http://dx.doi.org/10.3897/zookeys.100.1533

12. YU XD, LUO TH, ZHOU HZ 2006 Distribution of carabid beetles among regenerating and natural forest types in Southwestern China. Forest Ecol Manage 231: 169-177 http://dx.doi.org/10.1016/j.foreco.2006.05.043

13. JOHANSSON T, HJÄLTÉN J, OLSSON J, DYNESIUS M, ROBERGE J-M 2016 Long-term effects of clear-cutting on epigaeic beetle assemblages in boreal forests. For Ecol Manage 359: 65-73

14. BOHÁČ J 1999 Staphylinid beetles as bioindicators. Agr Ecosyst Environ 74: 357-372 http://dx.doi.org/10.1016/S0167-8809(99)00043-2

15. MAGURA T, NAGY D, TÓTHMÉRÉSZ B 2013 Rove beetles respond heterogeneously to urbanization. J Insect Conserv 17: 715724 http://dx.doi.org/10.1007/s10841-013-9555-y

16. POHL GR, LANGOR DW, SPENCE JR 2007 Rove beetles and ground beetles (Coleoptera: Staphylinidae, Carabidae) as indicators of harvest and regeneration practices in western Canadian foothills forests. Biol Conserv 137: 294-307 http://dx.doi.org/10.1016/j.biocon.2007.02.011

17. MAGURA T, LÖVEI GL, TÓTHMÉRÉSZ B 2010 Does urbanization decrease diversity in ground beetle (Carabidae) assemblages? Global Ecol Biogeogr 19: 16-26 http://dx.doi.org/10.1111/j.1466-8238.2009.00499.x

18. TÖRÖKP, TÓTHMÉRÉSZ B 2004 A debreceni Nagyerdő növényzeti arculatának vizsgálata. [Botanical survey of the Nagyerdő Forest]. Termvéd Közl 11: 107-116

19. MARTIN JEH 1977 Collecting, preparing, and preserving insects, mites, and spiders. Part 1 . The Insects and arachnids of 
Canada. Department of Agriculture Publication, Ottawa Hull, Que, p 182

20. DAVID JF, DEVERNAY S, LOUCOUGARAY G, LE FLOC'H E 1999 Belowground biodiversity in a Mediterranean landscape: relationships between saprophagous macroarthropod communities and vegetation structure. Biodivers Conserv 8: 753-767

21. TÓTHMÉRÉSZ B, NAGY DD, MIZSER S, BOGYÓ D, MAGURA T 2014 Edge effects on ground-dwelling beetles (Carabidae and Staphylinidae) in oak forest-forest edge-grassland habitats in Hungary. Eur J Entomol 111: 686-691

22. BOGYÓ D, MAGURA T, NAGY DD, TÓTHMÉRÉSZ B 2015 Distribution of millipedes (Myriapoda, Diplopoda) along a forest interior - forest edge - grassland habitat complex. Zookeys 510: 181-195 http://dx.doi.org/10.3897/zookeys.510.8657

23. SHAVRIN AV 2009 Impact of industrial pollutions on forest communities of rove beetles (Coleoptera, Staphylinidae) in Shelekhov raion of Irkutsk oblast. Contemp Probl Ecol 2: 40-45 http://dx.doi.org/10.1134/S199542550901007X

24. ASSING V, SCHÜLKE M 2011 Freude-Harde-Lohse-Klausnitzer - Die Käfer Mitteleuropas. Band 4 Staphylinidae I Zweite neubearbeitete Auflage. Spektrum Akademischer Verlag, Heidelberg und Berlin, pp 1-560

25. LOHSE GA 1974 Staphylinidae II (Hypocyphtinae und Aleocharinae) Pselaphidae, Bd. 5. In: Freude VH, Harde KW, Lohse GA (eds). Die Käfer Mitteleuropas. Goecke \& Evers Verlag, Krefeld, pp 1-304

26. HŮRKA K 1996 Carabidae of the Czech and Slovak republics. Karbourek, Zlin, p 565

27. TÓTHMÉRÉSZ B 1995 Comparison of Different Methods for Diversity Ordering. J Veg Sci 6: 283-290 http://dx.doi.org/10.2307/3236223

28. KINDT R, COE R 2005 Tree diversity analysis: A manual and software for common statistical methods for ecological and biodiversity studies. World Agroforestry Centre, Nairobi, Kenya, p 196

29. TÓTHMÉRÉSZ B 1998 On the characterization of scaledependent diversity. Abstr Bot 22: 149-156

30. LÖVEI GL 2005 Generalised entropy indices have a long history in ecology - a comment. Community Ecol 6: 245-247 http://dx.doi.org/10.1556/ComEc.6.2005.2.13

31. BERGER WH, PARKER FL 1970 Diversity of planktonic foraminifera in deep-sea sediments. Science 168: 1345-1347 http://dx.doi.org/10.1126/science.168.3937.1345
32. KOCH K 1989 Die Käfer Mitteleuropas. Ökologie. Band 1. Goecke \& Evers Verlag, Krefels, p 440

33. KOIVULA M 2002 Boreal carabid-beetle (Coleoptera, Carabidae) assemblages in thinned uneven-aged and clear-cut spruce stands. Ann Zool Fenn 39: 131-149

34. BUDDLE CM, LANGOR DW, POHL GR, SPENCE JR 2006 Arthropod responses to harvesting and wildfire: Implications for emulation of natural disturbance in forest management. Biol Conserv 128: 346-357 http://dx.doi.org/10.1016/j.biocon.2005.10.002

35. SKŁODOWSKI J 2014 Consequence of the transformation of a primeval forest into a managed forest for carabid beetles (Coleoptera: Carabidae) - a case study from Bialowieza (Poland). Eur J Entomol 111: 639-648 http://dx.doi.org/10.14411/eje.2014.088

36. LUO TH, YU XD, ZHOU HZ 2013 Effects of Reforestation Practices on Staphylinid Beetles (Coleoptera: Staphylinidae) in Southwestern China Forests. Environ Entomol 42: 7-16 http://dx.doi.org/10.1603/EN11298

37. DERUNKOV AV 2005 Changes in species diversity of rove beetles (Coleoptera, Staphylinidae) depending on the age of pine plantations in central Belarus. Russ J Ecol 36: 277-284 http://dx.doi.org/10.1007/s11184-005-0073-3

38. GALLÉ R, MAÁK I, SZPISJAK N 2014 The effects of habitat parameters and forest age on the ground dwelling spiders of lowland poplar forests (Hungary). J Insect Conserv 18: 791-799 http://dx.doi.org/10.1007/s10841-014-9686-9

39. MÜCKE W, DEÁK B, SCHROIFF A, HOLLAUS M, PFEIFER N 2013 Detection of fallen trees in forested areas using small footprint airborne laser scanning data. Can J Remote Sens 39: 32-40 http://dx.doi.org/10.5589/m13-013

40. REDON M, LUQUE S, GOSSELIN F, CORDONNIER T 2014 Is generalisation of unevenaged management in mountain forests the key to improve biodiversity conservation within forest landscape mosaics? Ann For Sci 71: 751-760 http://dx.doi.org/10.1007/s13595-014-0371-7

41. SIIRA-PIETIKAINEN A, HAIMI J 2009 Changes in soil fauna 10 years after forest harvestings: Comparison between clear felling and green-tree retention methods. Forest Ecol Manage 258: 332338 http://dx.doi.org/10.1016/j.foreco.2009.04.024

42. KUULUVAINEN T, TAHVONEN O, AAKALA T 2012 EvenAged and Uneven-Aged Forest Management in Boreal Fennoscandia: A Review. Ambio 41: 720-737 http://dx.doi.org/10.1007/s13280-012-0289-y 
Appendix 1 Collected ground beetle and rove beetle species and their classification based on works of Hirka (1996) and Koch (1989) and also on our field experience in the stages of the silvicultural cycle.

\begin{tabular}{|c|c|c|c|c|c|}
\hline Species & 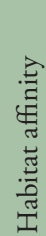 & 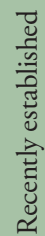 & 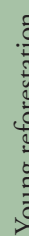 & & 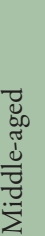 \\
\hline
\end{tabular}

\section{Ground beetles}

Acupalpus parvulus

Amara aenea

Amara bifrons

Amara convexior

Amara familiaris

Amara fulva

Amara lucida

Amara ovata

Amara saphyrea

Amara tibialis

Badister bullatus

Bembidion lampros

Bembidion quadrimaculatum

Calathus erratus

Calathus fuscipes

Calathus melanocephalus

Carabus convexus

Harpalus distinguendus

Harpalus flavescens

Harpalus latus

Harpalus modestus

Harpalus picipennis

Harpalus pumilus

Harpalus smaragdinus

Harpalus tardus

Harpalus xanthopus winkleri

Masoreus wetterhalli

Microlestes minutulus

Notiophilus palustris

Notiophilus rufipes

Ophonus rufibarbis

Oxypselaphus obscurus

Parophonus complanatus

Philorhizus notatus

Platyderus rufus

Pseudoophonus griseus

Pseudoophonus rufipes

Pterostichus oblongopunctatus

Pterostichus strenuus

Syntomus obscuroguttatus

Syntomus pallipes

Synunchus vivalis

Trechus quadristriatus

Rove beetles

Alaobia scapularis

Aleochara bipustulata

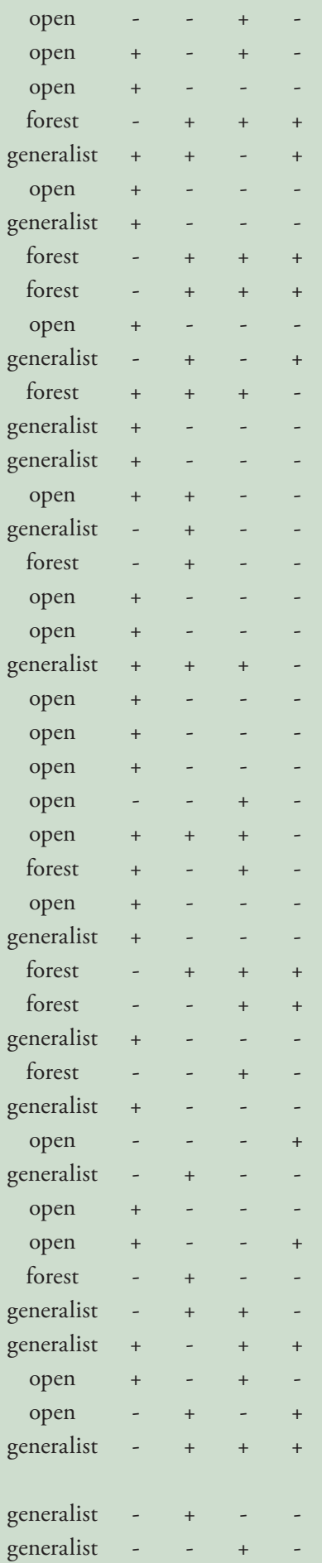

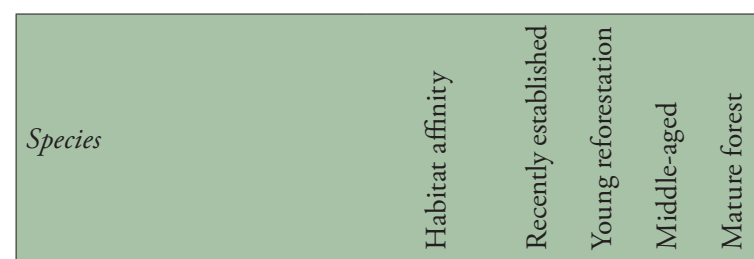

Amauronyx maerkelii

Amischa analis

Anthobium atrocephalum

Astenus procerus

Atheta benickiella

Atheta euryptera

Atheta fungi

Atheta gagatina

Atheta harwoodi

Atheta negligens

Atheta orbata

Atheta voeslauensis

Batrisodes adnexus

Bolitiobius castaneus

Bolitochara bella

Brachida exigua

Bryaxis carinula

Bryaxis curtisii orientalis

Carpelimus sp

Cousya nigata

Dropephylla ioptera

Falagrioma thoracica

Gabrius osseticus

Geostiba circellaris

Gyrohypnus angustratus

Gyrophaena fasciata

Gyrophaena joyioides

Habrocerus capillaricornis

Heterothops dissimilis

Ischnosoma splendidum

Lathrobium geminum

Liogluta granigera

Liogluta longiuscula

Lordithon thoracicus

Medon fusculus

Metopsia similis

Mycetoporus eppelsheimianus

Mycetoporus erichsonanus

Mycetoporus forticornis

Mycetoporus rufescens

Mycetota laticollis

Ocalea badia

Ocypus nitens

Omalium caesum

Omalium rivulare

Ontholestes haroldi

Othius punctulatus

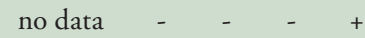

generalist

generalist

open

forest

generalist

generalist

forest

$-\quad-\quad+$

forest - - -+

generalist +-++

open - - + -

no data - - $\quad+$

generalist - -++

generalist - -++

open - - - +

no data - $+\quad+\quad+$

no data - + + +

no data - + $\quad$ -

open + - - -

generalist - - $\quad+$

generalist - $\quad-\quad+$

generalist -+++

generalist -+++

generalist - $+\quad+$

forest $-{ }_{-}+$

generalist - - $\quad+$

generalist - -++

generalist ++++

generalist - ++

generalist - $++\quad-$

generalist - - -+

generalist - $\quad-\quad+$

generalist - - + +

generalist ++++

forest - +

generalist - + +

generalist - + - -

generalist - + - -

generalist - $-+\quad+$

generalist -+++

generalist - +-+

generalist -+++

generalist - $\quad-\quad+$

generalist - +

generalist - +++ forest - $+\quad-$ 


\begin{tabular}{|c|c|c|c|c|c|}
\hline Species & 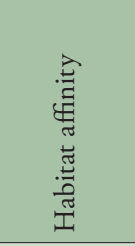 & 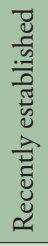 & 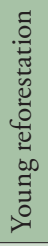 & 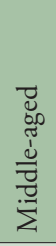 & 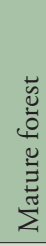 \\
\hline Oxypoda abdominalis & generalist & - & + & + & + \\
\hline Oxypoda acuminata & generalist & - & - & + & + \\
\hline Oxypoda flavicornis & forest & - & + & - & + \\
\hline Oxypoda opaca & generalist & - & - & + & - \\
\hline Oxypoda togata & generalist & + & - & - & - \\
\hline Oxypoda vicina & generalist & + & - & - & - \\
\hline Pella laticollis & generalist & - & - & - & + \\
\hline Pella ruficollis & forest & - & - & - & + \\
\hline Philonthus concinnus & generalist & + & - & - & - \\
\hline Philonthus succicola & generalist & - & + & - & - \\
\hline Phyllodrepa melanocephala & forest & - & - & - & + \\
\hline Pselaphus heisei & generalist & - & + & + & + \\
\hline Quedius curtipennis & generalist & - & + & - & + \\
\hline Quedius fuliginosus & generalist & - & - & - & + \\
\hline Quedius limbatus & forest & - & + & + & + \\
\hline Quedius scintillans & generalist & + & - & - & + \\
\hline Rabigus pullus & generalist & + & - & - & - \\
\hline Rugilus rufipes & forest & - & - & + & + \\
\hline Rugilus subtilis & generalist & - & - & + & - \\
\hline Scaphidium quadrimaculatum & forest & - & + & - & + \\
\hline Scaphium immaculatum & generalist & - & + & + & - \\
\hline Scopaeus pusillus & open & + & - & - & - \\
\hline Sepedophilus immaculatus & generalist & - & + & - & - \\
\hline Sepedophilus marshami & generalist & - & + & + & + \\
\hline Sepedophilus obtusus & generalist & + & + & + & - \\
\hline Sepedophilus pedicularis & generalist & - & + & - & - \\
\hline Sepedophilus testaceus & generalist & - & - & + & + \\
\hline Stenus ater & open & + & + & - & - \\
\hline Stenus clavicornis & open & + & + & - & - \\
\hline Stenus humilis & forest & - & + & + & - \\
\hline Stenus ludyi & forest & - & + & + & + \\
\hline Stenus ochropus & generalist & + & + & + & + \\
\hline Sunius fallax & generalist & + & + & + & + \\
\hline Tachinus fimetarius & generalist & - & - & - & + \\
\hline Tachyporus atriceps & generalist & - & - & - & + \\
\hline Tachyporus chrysomelinus & generalist & - & - & + & - \\
\hline Tachyporus hypnorum & generalist & + & + & + & + \\
\hline Tachyporus nitidulus & generalist & - & + & + & + \\
\hline Tasgius morsitans & generalist & - & - & - & + \\
\hline Thinonoma atra & generalist & - & - & - & + \\
\hline Xantholinus longiventris & generalist & - & + & - & - \\
\hline Zyras collaris & generalist & - & - & + & - \\
\hline Zyras haworthi & generalist & - & - & - & + \\
\hline
\end{tabular}


